\title{
The Effects of Biomechanical Factors to Teach Different Hook Punch Techniques in Boxing and Education Strategies
}

\author{
Bergun Meric Bingul ${ }^{1}$, Cigdem Bulgan ${ }^{2}$, Ozlem Tore ${ }^{1}$, Erdal Bal $^{3}$, Mensure Aydin $^{1}$ \\ ${ }^{1}$ Kocaeli University, Faculty of Sport Science \\ ${ }^{2}$ Halic University, School of Physical Education and Sport \\ ${ }^{3}$ Ankara University, Faculty of Sport Science \\ Correspondence: Cigdem Bulgan, School of Pyhsical Education and Sports, Halic University, İstanbul, Levent Cad. \\ No.51 Besiktas, 34350, Turkey.
}

Received: December 12, 2017

Accepted: February 5, $2018 \quad$ Online Published: April 1, 2018

doi:10.11114/jets.v6i3a.3153

URL: https://doi.org/10.11114/jets.v6i3a.3153

\begin{abstract}
The aim of this study was to investigate the effects of biomechanic factors to teach different hook punches in boxing. Eight light middleweight boxing athletes (mean age \pm SD $19.00 \pm 2.00 \mathrm{yrs}$, mean height \pm SD $173.88 \pm 3.89 \mathrm{~cm}$, mean weight \pm SD $64.25 \pm 4.66 \mathrm{~kg}$ ) participated in this study. Athletes performed a trial using three different hook punch techniques on a sandbag. The techniques were recorded using eight cameras using a frequency of $120 \mathrm{~Hz}$. Qualisys Track Manager was used to analysis on motion. Mean acceleration of the sandbag, stride length, angles of the knee, shoulder, and elbow were calculated. The forces of impact were also calculated. Hook punch data were compared with Friedman test using SPSS 20.0. The results indicated a significant difference was found only in stride length. Stride length using a southpaw stance was shorter than the other stances $(\mathrm{p}<0.05)$. Athletes need more practice increasing stride length and use a repeating method in Mitt workout, models, sandbag trainings, self- monitoring and regional trainings.
\end{abstract}

Keywords: boxing, punch, biomechanic, education, strategies.

\section{Introduction}

Boxing art has the basic philosophy of punching and protecting from being punched. It is an art of defence that requires skills that need to be practiced to succeed (Pala, 2011). Boxing has a complex structure at a high level due to its dynamic and static characteristics and is among the combat sports that require a high degree of strength, endurance, stamina, agility, coordination, and speed (Sarış1k, 2014; Mack, Stojsih, Sherman, Dau, \& Bir, 2010).

The punch is a key component of boxing. It is used to create physical damage, improve tactical advantage and score points against an opponent (Lenetsky, Harris, \& Brughelli, 2013). Three basic punch styles are primarily used in boxing. They are straight, overhead and hook punches. Each of these requires different techniques. According to the positions of each opponent during the match, each boxer decides which stroke to use (Sarışık, 2014). It is known which punch type and combination can reach their intended target in the minimum time and also which generate the greatest impact of force (Piorkowski, Lees, \& Barton, 2011).

The hook is a type of punch where the arm is pulled at a 45 degree angle from the elbow, using strength from the hip and shoulder and moving the center of gravity towards the center of the opponents. It is a generally a stroke type used up close and more risky in terms of receiving punches back compared to the straight punch (Çakmakçı, 2002). A hook punch is used to hit the opponent's chin and the risk of being knocked out is higher when hit on the chin than other parts of the body (Walilko, Viano, \& Bir, 2005).

Another important factor in boxing, is the boxers stance position. There are two possible stance positions that can be used when hook punching. One of them is the orthodox stance, and the other is the southpaw stance. The term "orthodox stance" refers to the positioning of the boxer's hands and feet with the left foot and hand forward, and the right foot and hand back - which is natural to a right-handed person. The term "southpaw stance" which is natural to left-handers, refers to having one's right foot and hand in the front, ie a reverse of the orthodox stance (Sorokowski, Sabiniewicz, \& Wacewicz, 2014; Busko et al., 2014). These standing positions are very important for the force to have 
an effective impact and analysis of the kinematic characteristics of punch type and punch combination modalities will help to inform coaches and athletes when preparing for a competition (Piorkowski, Lees, \& Barton, 2011). The aim of this study is to investigate the effects of kinetic and kinematic factors in teaching different hook punch techniques in boxing. The secondary aim of the study is to understand teaching strategies of these techniques.

\section{Method}

This study was designed as for boxing athletes. Eight $(\mathrm{N}=8)$ light middleweight elite boxing athletes who represented the Turkish National Team in various times (mean age \pm SD 19.00 $\pm 2.00 \mathrm{yrs}$, mean height \pm SD $173.88 \pm 3.89 \mathrm{~cm}$, mean weight \pm SD $64.25 \pm 4.66 \mathrm{~kg}$ ) were recruited to participate in this study. The athletes had not experienced any upper and lower extremity injuries previously. The study was conducted within the recommendations of the Declaration of Helsinki. Before participating in the study, the athletes were informed about the research, including potential the risks and benefits of the study. Written consent was obtained from all the athletes.

\subsection{Data Collection Tools}

The collection of data was undertaken in Kocaeli Municipality, Seka Sports Hall, Kocaeli. All participants were asked to refrain from alcohol, caffeine and ergogenic aids the day before the test. The procedure included a 15 min warm up time for the athletes which included A $5 \mathrm{~min}$ jog and $10 \mathrm{~min}$ of dynamic stretching with some specific movements (for femur, calf, ankle, shoulder, arm, abdominal and core muscles). Dynamic exercises were applied 10-15 rep. with $15 \mathrm{sec}$ resting time between.

The reflector markers $3 \mathrm{~cm}$ in diameter were attached to selected joints on each athlete. Eleven segment models were used for the determination of kinematic variables (calf, leg, punch, upper arm, lower arm, trunk). The sandbag had markers attached for the calculation of the force of impact. These markers were attached to the athletes with double-sided tape (Figure 1).

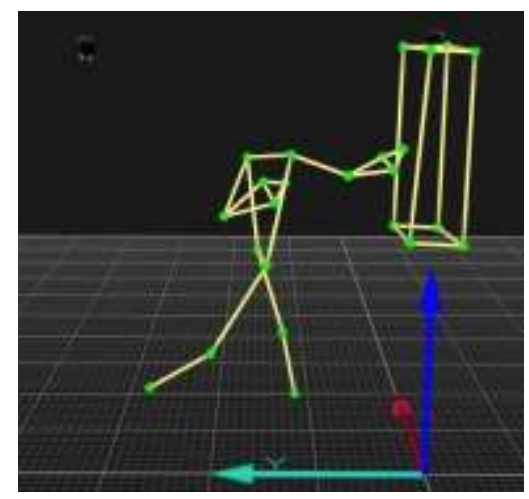

Figure 1. Reflective Markers and 3D Diagram

Kinematic data were collected using $120 \mathrm{~Hz}$ frequency, 8 high-speed Oqus $7+$ cameras (Dimensions: $18.7 \times 11 \times 12.5 \mathrm{~cm}$; Weight: $1.9-2.1 \mathrm{~kg}$ ) which was connected directly to a computer. The cameras were placed about 3-4 $\mathrm{m}$ distance from each other and 4-6 m from the participants. For analyses of the 3D angular kinematics, Qualisys Track Manager (QTM) Version 2.12 was used. A dynamic wand calibration method was used. The T stick was moved around in the volume while a stationary reference object within the volume defined the coordinate system for the motion captured. Calibration time was set for $45 \mathrm{sec}$. Marker trajectories used were low pass filtered at $5 \mathrm{~Hz}$ using Butterworth filter.

Athletes performed a trial using three different hook punch techniques (Orthodox stance, Southpaw stance and Tall stroke) on a sandbag. The techniques were recorded at a frequency of $120 \mathrm{~Hz}$ using eight synchronized high-speed cameras (Oqus 7+). Qualisys Track Manager (Qualisys, Sweden) was performed for three-dimensional motion analysis. Wand calibration method (with T stick) was used for field calibration. Mean acceleration of the sandbag, stride length, angles of the knee, shoulder, and elbow were calculated. The impact forces of the hook punches, and punch (hand) linear velocity and acceleration were also calculated. Forces were calculated using the sandbag mass $(48.80 \mathrm{~kg})$ and the formula of $\mathrm{F}=\mathrm{ma}$ and impulse was calculated using the formula of: $\mathrm{I}=\mathrm{F} \Delta \mathrm{t}$

\subsection{Statistical Analysis Techniques}

The data of different hook punches were statistically analysed using SPSS 20.0 (SPSS Inc., Chicago, IL, USA) program. The results were presented as Means \pm SD. The Friedman test was utilized to identify any significant difference between specific punch techniques and the MannWhitney-U test was used as a Post Hoc. The statistical significance level was set at $\mathrm{P}<0.05$. 


\section{Results}

The findings of this study are shown in Tables 1 and 2. The impact force of the different hook punch techniques were found to be $1462.41 \pm 371.61 \mathrm{~N}$ for the Southpaw Stance, $1501.08 \pm 316.18 \mathrm{~N}$ for the Orthodox Stance and 1578.49 $\pm 220.05 \mathrm{~N}$ for the Tall Stroke (Table 1).

Table 1. Descriptive Statistics of Kinematic Variables of Different Hook Punches

\begin{tabular}{cccc}
\hline & Southpaw Stance & Orthodox Stance & Tall Stroke \\
\hline Variables & (Mean \pm Std.Dev) & $\underline{\text { Mean } \pm \text { Std.Dev })}$ & (Mean \pm Std.Dev) \\
Stride Lengths $(\mathrm{cm})$ & $66.97 \pm 15.34$ & $84.74 \pm 7.88$ & $89.69 \pm 8.96$ \\
Elbow Angle $\left(^{\circ}\right)$ & $102.85 \pm 4.64$ & $98.10 \pm 8.44$ & $101.01 \pm 5.83$ \\
Knee Angle $\left({ }^{\circ}\right)$ & $155.60 \pm 13.79$ & $156.92 \pm 10.18$ & $158.72 \pm 5.23$ \\
Shoulder Angle $\left({ }^{\circ}\right)$ & $75.52 \pm 7.23$ & $71.77 \pm 6.86$ & $77.11 \pm 7.13$ \\
Punch (Hand) Velocity $(\mathrm{m} / \mathrm{s})$ & $1.61 \pm 1.35$ & $1.58 \pm 1.30$ & $1.48 \pm 0.59$ \\
Punch $\left(\right.$ Hand) Acceleration $\left(\mathrm{m} / \mathrm{s}^{2}\right)$ & $317.89 \pm 138.47$ & $353.80 \pm 72.98$ & $299.89 \pm 114.70$ \\
Sandbag Acceleration $\left(\mathrm{m} / \mathrm{s}^{2}\right)$ & $29.96 \pm 7.61$ & $30.76 \pm 6.47$ & $32.34 \pm 4.50$ \\
Impact Force $(\mathrm{N})$ & $1462.41 \pm 371.61$ & $1501.08 \pm 316.18$ & $1578.49 \pm 220.05$ \\
\hline
\end{tabular}

The results suggest that only stride lengths between different hook punch techniques was statistically significantly different (Table 2). Stride length of the Southpaw stance position during a hook punch technique was shorter $(66.97 \pm 15.34 \mathrm{~cm})$ compared to the others $(\mathrm{p}<0.05)($ Table 1$)$. There were no other statistically significant differences between other kinetic and kinematic parameters (Table 1).

Table 2. Statistical Results of Kinematic Variables of the Different Hook Punches

\begin{tabular}{cc}
\hline Variables & Asymp.Sig \\
\hline Stride Lengths $(\mathrm{cm})$ & $0.000^{*}$ \\
Elbow Angle $\left(^{\circ}\right)$ & 0.072 \\
Knee Angle $\left(^{\circ}\right)$ & 0.607 \\
Shoulder Angle $\left(^{\circ}\right)$ & 0.197 \\
Punch Velocity $(\mathrm{m} / \mathrm{s})$ & 0.798 \\
Punch Acceleration $\left(\mathrm{m} / \mathrm{s}^{2}\right)$ & 0.417 \\
Sandbag Acceleration $\left(\mathrm{m} / \mathrm{s}^{2}\right)$ & 0.687 \\
Impact Force $(\mathrm{N})$ & 0.687 \\
\hline
\end{tabular}

$* \mathrm{p}<0.05$

\section{Discussion}

This study aims to investigate the differences of kinematic and kinetic factors in teaching different hook punch techniques in boxing. The velocities, accelerations and forces of the hook punch types and sandbags, and also some segment angles on impact were calculated. The only statistically different result was found in differing stride lengths between different type of hook punch $(\mathrm{p}<0.005)$. Although the statistical difference was not significant, the impact force increased as the stride length increased. This suggests that the expansion of the stride surface increased the control of motion and allowed for a stronger punch. The greatest impact force was obtained from tall strokes with a width stride. Reports in the literature have focused on boxing related injuries (Zazryn, Cameron, \& McCrory, 2006) and the effects of punch biomechanics (Sherman, Bir, Walilko, \& Boitano, 2004; Walilko, Viano, \& Bir, 2005; Mack, Stojsih, Sherman, Dau, \& Bir, 2010). The hand velocity and punch force correlated strongly (Walilko, Viano, \& Bir, 2005; Kimm \& Thiel, 2015) and post-hoc analysis suggests that the contact velocity of a hook punch is significantly greater in the Lead and Reverse Hook punches, compared to Jab and Cross punches (Piorkowski, Lees, \& Barton, 2011). The average velocities at contact ranged from 5.9 to $8.2 \mathrm{~m} / \mathrm{s}$, with peak velocities of 6.6 to $12.5 \mathrm{~m} / \mathrm{s}$ reaching 8 to $21 \mathrm{~m} / \mathrm{s} \mathrm{prior} \mathrm{to} \mathrm{hand/glove}$ contact with the sandbag. Kimm \& Thiel (2015) measured a hand peak velocity as high as $9 \mathrm{~m} / \mathrm{s}$, depending on the type of punch - jab, cross, lead hook and reverse hook. In this study, punch velocities were $1.61 \pm 1.35 \mathrm{~m} / \mathrm{s}$ for Orthodox Stance; $1.58 \pm 1.30 \mathrm{~m} / \mathrm{s}$ for Southpaw Stance and $1.48 \pm 0.59 \mathrm{~m} / \mathrm{s}$ for Tall Hook Punch. These results were lower than that reported in the literature. The reason for this is that the hand velocity before impact at the sandbag was not calculated.

To effectively manage the physical and/or technical tactical requirements of an amateur boxing match, boxers should have well-developed muscle strength and power. Muscle strength in both the upper and lower limbs is paramount to maintain boxer's level of competitiveness. The boxing punch is a brief action and extremely dynamic, and therefore high level amateur boxing performance requires well-developed muscular power. Upper and lower limb muscular power are positively correlated in boxers (Vecchio, 2011). Mack, Stojsih, Sherman, Dau, \& Bir (2010) evaluated the correlation between a boxers' biomechanics and their punch force for two different punches. It was determined that 
punch force correlated more closely to hand velocity, than to lower body force. Impact force for a single maximal boxing punch by elite boxers ranges between $3500 \mathrm{~N}$ and $4800 \mathrm{~N}$ (Smith, Dyson, Hale, \& Janaway, 2000; Walilko, Viano, \& Bir, 2005). Punches in competition (in the ring) or simulated combination punches (in the laboratory) produce around half the impact force of single maximal punches (Pierce, Reinbold, Lyngard, Goldman, \& Pastore, 2006; Smith, 2006; Stojsih, Boitano, Wilhelm, \& Bir, 2010). The Hook punch has a round, semi-circular technique aimed at either the head or body. Punch force correlates with hand velocity $(\mathrm{R}=0.380)$ for hook punches (Mack, Stojsih, Sherman, Dau, \& Bir, 2010). A difference in punching force has determined (Smith, Dyson, Hale, \& Janaway, 2000) between both lead and rear hand techniques; the lead hand hook averages $1412 \mathrm{~N}$, while the rear hand averages $2588 \mathrm{~N}$. The increase in lead hand hook force compared to the straight lead hand may be attributed to the increase in body rotation associated with the technique when throwing a lead hand hook punch (Smith, Dyson, Hale, \& Janaway, 2000; Smith, 2006). In this study, impact forces were $1462.41 \pm 371.61 \mathrm{~N}$ for Orthodox Stance; $1501.08 \pm 316.18 \mathrm{~N}$ for Southpaw Stance and $1578.49 \pm 220.05 \mathrm{~N}$ for Tall Hook Punch. There was no significant differences found between the different techniques. Hand velocity may be one reason for this because a hook punch has different characteristics and has high correlation between hand velocity and acceleration (Bingül, Bulgan, Bal, Tore, Aydin, \& 2017). However, Bingül, Bulgan, Bal, Tore, \& Aydin (2017) reports greater impact forces and accelerations in the Orthodox stance position and recommends that it be used instead of the Southpaw stance for a straight punch technique, especially for creating greater impact forces. In this study, there was no significant difference found between different stances to support hook punches, with the forces measured very similar (Table 1).

\subsection{Education Strategies and Teaching the Techniques}

The hook is technically important punch for a hit. Hooks to the body mostly need to be thrown from close range, therefore a good solid defence has to be practised (Blower, 2007). In general, punches on the jaw often end in a knockout. For this reason, it is necessary to work intensively to develop this technique. During training, the body rotation of the athlete's hook strike increases the effectiveness of the first force. At the same time, the coupling of the hip and foot rotation completes the hook stroke.

In order to reach adequate levels in hook technique, boxers training in front of mirrors must continuously repeat hook strokes and try to achieve the required angle and acceleration When learning the hook strike technique athletes must work with a coach, to ensure that the punch finishes by performing force transmission, body and arm rotation for an effective stroke. In order to make the body and arm rotations more effective, there are some exercises in which hook bags are repeatedly hit with right and left hand hook strokes. Working at the same time with a partner for more effective training, long distance strokes at close range, short distance strokes and medium distance work increase the rate of success.

\section{Conclusion}

In conclusion, boxing is a sport that can be won after performing effective punches and strokes during the match. For that reason, teaching different strokes and choosing an optimal one in competition according to the body position, is an advantage. In order to achieve success in competition, some physical parameters, such as speed, stability, psychological threshold, technical capacity, explosive power and endurance, need to be reflected in technique within a coordinated manner at an elite level.

\section{Recommendations}

Boxers should have an intensive and extensive training process to achieve an elite level. In some studies it has been reported that a result of correct reflection of specific techniques, using correct body rotation, motion angles and force transfer in the right proportions, supports more effective and accurate strokes. Athletes should increase their practice and use a repeating method in Mitt workout, models, sandbag trainings, self-monitoring and regional trainings. Additionally, expanding the stride stance will provide stability and effect the punch strength positively.

\section{References}

Bingül, M. B., Bulgan, C., Bal, E., Tore, O., \& Aydin, M. (2017). Elit Boksörlerde Farklı Vuruş Teknikleri İle Üretilen İmpuls Kuvveti Farklılıklarının Belirlenmesi. The International Balkan Conference in Sport Sciences 21 - 23 May, Bursa, Turkey.

Blower, G. (2012). Boxing: Training, skills and techniques. The Crowood Press Ltd, England.

Buśko, K., Staniak, Z., Łach, P., Mazur-Różycka, J., Michalski, R., \& Górski, M. (2014). Comparison of two boxing training simulators. Biomedical Human Kinetics, 6(1). https://doi.org/10.2478/bhk-2014-0022

Çakmakçı, O. (2002). Türkiye ve Gürcistan A Milli Boks Takımlarının seçilmiş fiziksel özelliklerinin karşılaştırılması(Doctoral dissertation, Selçuk Üniversitesi Sağlık Bilimleri Enstitüsü). 
Kimm, D., \& Thiel, D. V. (2015). Hand speed measurements in boxing. Procedia Engineering, 112, 502-506. https://doi.org/10.1016/j.proeng.2015.07.232

Lenetsky, S., Harris, N., \& Brughelli, M. (2013). Assessment and contributors of punching forces in combat sports athletes: Implications for strength and conditioning. Strength \& Conditioning Journal,35(2), 1-7. https://doi.org/10.1519/SSC.0b013e31828b6c12

Mack, J., Stojsih, S., Sherman, D., Dau, N., \& Bir, C. (2010). Amateur boxer biomechanics and punch force. In ISBS-Conference Proceedings Archive (Vol. 1, No. 1).

Pala, R., \& Savucu, Y. (2011). Boks milli takımının avrupa şampiyonasına hazırlık kampları süresince bazı fiziksel ve oksidatif stres parametrelerinin incelenmesi. Firat Üniversitesi Sağllk Bilimler Enstitüsü Beden Eğitimi ve Spor Ana Bilim Dall.

Pierce, J. D., Reinbold, K. A., Lyngard, B. C., Goldman, R. J., \& Pastore, C. M. (2006). Direct measurement of punch force during six professional boxing matches. Journal of Quantitative Analysis in Sports, 2(2). https://doi.org/10.2202/1559-0410.1004

Piorkowski, B. A., Lees, A., \& Barton, G. J. (2011). Single maximal versus combination punch kinematics. Sports Biomechanics, 10(01), 1-11. https://doi.org/10.1080/14763141.2010.547590

Sarışık, D. (2014). Türk Genç Erkek Boks Milli Takımı Sporcuları İle Ankara İlinde Genç Erkek Amatör Düzeyde Boks Yapan Sporcuların, Fizikseli, Antropometrik, Bazı Motorik ve Somatotip Özelliklerinin Karşılaştırılması, Yüksek Lisans Tezi, Dumlupınar Üniversitesi Sağlık Bilimleri Enstitüsü Beden Eğitimi ve Spor Anabilim Dalı, Kütahya.

Sherman, D., Bir, C., Walilko, T., \& Boitano, M. (2004). Correlation between punch dynamics and risk of injury. In 5th Conference on Engineering of Sport, UC Davis, CA (pp. 110-116).

Smith, M. S. (2006). Physiological profile of senior and junior England international amateur boxers. Journal of sports science \& medicine, 5 (CSSI), 74.

Smith, M. S., Dyson, R. J., Hale, T., \& Janaway, L. (2000). Development of a boxing dynamometer and its punch force discrimination efficacy. Journal of sports sciences, 18(6), 445-450. https://doi.org/10.1080/02640410050074377

Sorokowski, P., Sabiniewicz, A., \& Wacewicz, S. (2014). The influence of the boxing stance on performance in professional boxers. AnthropologicAl review, 77(3), 347-353. https://doi.org/10.2478/anre-2014-0025

Stojsih, S., Boitano, M., Wilhelm, M., \& Bir, C. (2010). A prospective study of punch biomechanics and cognitive function for amateur boxers. British Journal of Sports Medicine, 44(10), 725-730. https://doi.org/10.1136/bjsm.2008.052845

Vecchio, L. D. (2011). Profiling the Physiology of an Amateur Boxer. Amature Boxing-A Scientific Review.

Walilko, T. J., Viano, D. C., \& Bir, C. A. (2005). Biomechanics of the head for Olympic boxer punches to the face. British journal of sports medicine, 39(10), 710-719. https://doi.org/10.1136/bjsm.2004.014126

Zazryn, T., Cameron, P., \& McCrory, P. (2006). A prospective cohort study of injury in amateur and professional boxing. British journal of sports medicine, 40(8), 670-674. https://doi.org/10.1136/bjsm.2006.025924

\section{Copyrights}

Copyright for this article is retained by the author(s), with first publication rights granted to the journal.

This is an open-access article distributed under the terms and conditions of the Creative Commons Attribution license which permits unrestricted use, distribution, and reproduction in any medium, provided the original work is properly cited. 